\title{
Bim Is Elevated in Alzheimer's Disease Neurons and Is Required for $\beta$-Amyloid-Induced Neuronal Apoptosis
}

\author{
Subhas C. Biswas, Yijie Shi, Jean-Paul G. Vonsattel, Conrad L. Leung, Carol M. Troy, and Lloyd A. Greene \\ Department of Pathology, Center for Neurobiology and Behavior and Taub Institute for Research on Alzheimer's Disease and the Aging Brain, Columbia \\ University College of Physicians and Surgeons, New York, New York 10032
}

The molecules that mediate neuron death in Alzheimer's disease (AD) are largely unknown. We report that $\beta$-amyloid (A $\beta$ ), a deathpromoting peptide implicated in the pathophysiology of $\mathrm{AD}$, induces the proapoptotic protein Bcl-2 interacting mediator of cell death (Bim) in cultured hippocampal and cortical neurons. We further find that Bim is an essential mediator of $A \beta$-induced neurotoxicity. Our examination of postmortem $\mathrm{AD}$ human brains additionally reveals upregulation of Bim in vulnerable entorhinal cortical neurons, but not in cerebellum, a region usually unaffected by AD. Accumulating evidence links inappropriate induction/activation of cell cycle-related proteins to $\mathrm{AD}$, but their roles in the disease have been unclear. We find that the cell cycle molecule cyclin-dependent kinase $4(\mathrm{cdk} 4)$ and its downstream effector B-myb, are required for $A \beta$-dependent Bim induction and death in cultured neurons. Moreover, neurons that overexpress Bim in AD brains also show elevated levels of the cell cycle-related proteins cdk 4 and phospho-Rb. Our observations indicate that Bim is a proapoptotic effector of $\mathrm{A} \beta$ and of dysregulated cell cycle proteins in $\mathrm{AD}$ and identify both Bim and cell cycle elements as potential therapeutic targets.

Key words: neuronal apoptosis; $\mathrm{BH} 3$ only; cell cycle; Alzheimer's disease; Bim; $\mathrm{A} \beta$ peptide

\section{Introduction}

Alzheimer's disease $(\mathrm{AD})$ is a progressive disorder characterized by selective neuron loss and formation of neurofibrillary tangles and of plaques containing amyloid- $\beta$ peptide $(\mathrm{A} \beta)$ (Masters et al., 1985; Wisniewski and Wegiel, 1995; Yankner, 1996; Hardy, 1997; Selkoe, 1999, 2001). Accumulating data indicate that A $\beta$ plays a central role in AD (Cotman et al., 1994; Cotman and Su, 1996; Yankner, 1996; Stadelmann et al., 1999; Selkoe, 2001). In addition to genetic evidence that $\mathrm{A} \beta$ promotes neuron degeneration and death in vivo, in vitro studies show that aggregated $\mathrm{A} \beta$ rapidly induces neuron death (Pike et al., 1991; Li et al., 1996; Estus et al., 1997; Troy et al., 2000; Hartman et al., 2005). However, the mechanisms by which neuron degeneration and death occur in $\mathrm{AD}$ and whereby these are induced by $\mathrm{A} \beta$ are incompletely understood.

One focus regarding the mechanism of neuron death in $\mathrm{AD}$ has been the aberrant neuronal expression of cell cycle-related proteins (for review, see Greene et al., 2004; Herrup et al., 2004; Webber et al., 2005). Although such observations in postmortem neurons have been correlative with susceptibility to death, in vitro studies have provided evidence that cycle-related proteins medi-

Received March 24, 2006; revised Dec. 12, 2006; accepted Dec. 15, 2006.

This work was supported in part by grants from the National Institutes of Health-National Institute of Neurological Disorders and Stroke (L.A.G., C.M.T.) and the Alzheimer's Disease Research Center at Columbia University AG08702 (M. Shelanski). We thank Katerina Mancevska for aid in preparing and providing brain tissue samples. We thank Dr. Michael L. Shelanski for critical reading of this manuscript and Drs. Giselle F. Prunell and Peter Canoll for helpful discussions.

Correspondence should be addressed to Subhas C. Biswas, Department of Pathology, Columbia University College of Physicians and Surgeons, P\&S 15-401,630 West 168th Street, New York, NY 10032. E-mail: scb34@columbia.edu. DOI:10.1523/JNEUROSCI.3524-06.2007

Copyright $\odot 2007$ Society for Neuroscience $\quad$ 0270-6474/07/270893-08\$15.00/0 ate neuron death in $\mathrm{AD}$. It was reported that $\mathrm{A} \beta$ activates cell cycle components in cultured neurons and that interference with such molecules by pharmacologic agents and dominant-negative constructs [cyclin-dependent kinases 4/6 (cdk4/6), in particular] protects from $A \beta$ toxicity (Giovanni et al., 1999, 2000).

Past studies have indicated similarities between the mechanisms by which trophic factor deprivation and $A \beta$ induce neuron death (Park et al., 1998; Giovanni et al., 1999, 2000; Troy et al., 2000, 2001; Liu and Greene, 2001; Greene et al., 2004; Liu et al., 2004, 2005; Biswas et al., 2005). This includes activation of cell cycle molecules and an apparent requirement for cdk4 activity. In the case of neurotrophic factor deprivation, a multistep pathway requiring $\mathrm{cdk} 4$ has been described that leads to induction of $\mathrm{Bcl}-2$ interacting mediator of cell death (Bim), a proapoptotic Bcl-2 family member (Puthalakath and Strasser, 2002; Biswas et al., 2005). Bim induction in turn plays an important role in neuron death evoked by trophic deprivation (Putcha et al., 2001; Linseman et al., 2002; Biswas et al., 2005; Ham et al., 2005). Because of the shared involvement of cell cycle molecules in death associated with trophic factor deprivation and $A \beta$ exposure, we hypothesized that the latter may also involve induction of Bim through a cdk4-dependent mechanism.

The present work identifies critical regulators of neuron death that act distally to $\mathrm{A} \beta$ and that are relevant to $\mathrm{AD}$. We report that Bim is induced by $A \beta$ in cultured neurons and that this is essential for $A \beta$-dependent neuron death. Bim appears directly pertinent to $\mathrm{AD}$ in that its expression is selectively elevated in susceptible neurons in postmortem AD brains. We further show that Bim induction by $\mathrm{A} \beta$ is mediated by $\mathrm{cdk} 4$ and plays a required role in $A \beta$-dependent apoptosis. Our observations thus outline an $\mathrm{AD}$-relevant pathway that sequentially links exposure to $\mathrm{A} \beta$, 
activation of cell cycle components, Bim induction, and promotion of neuron death.

\section{Materials and Methods}

Preparation of amyloid. Lyophilized, HPLC-purified $\mathrm{A} \beta_{1-42}$ was purchased from American Peptide (Sunnyvale, CA). A $\beta_{1-42}$ was reconstituted in sterile water at a concentration of $400 \mu \mathrm{M}$ as described previously (Troy et al., 2000). Aliquots of stocks were incubated at $37^{\circ} \mathrm{C}$ for $3 \mathrm{~d}$ to form aggregated amyloid. Oligomeric $\mathrm{A} \beta$ was prepared as described previously (Barghorn et al., 2005).

Primary neuron culture. Embryonic rat cortical, and hippocampal neurons were cultured as previously described (Park et al., 1998; Troy et al., 2000).

Western immunoblotting. Human brain tissues were dissolved in $2 \times$ sample buffer by sonication. Bim protein expression was analyzed by Western immunoblotting as described previously (Biswas and Greene, 2002). The extracellular signal-regulated kinase 1 (ERK1) antibody was from Santa Cruz Biotechnology (Santa Cruz, CA) and the Bim antibody was from StressGen (Victoria, British Columbia, Canada). Western blots were scanned and analyzed by NIH Image J to provide quantitative values for relative expression of Bim protein (normalized to ERK protein). The statistical significance of changes was tested by the paired $t$ test.

Reverse transcription-quantitative PCR. Each sample of total RNA was isolated from cultured neurons by using TRI reagent (Molecular Research Center, Cincinnati, $\mathrm{OH}$ ) and was from human brain samples by using Trizol reagent (Invitrogen, San Diego, CA). cDNA was transcribed from total RNA with Superscript RT II (Invitrogen). The primers used for PCR amplification of rat Bim were $5^{\prime}$-GCCCCTACCTCCCTACAGAC-3' and 5'-CCTTATGGAAGCCATTGCAC-3'. The primers used for PCR amplification of human Bim were 5'-CACATGAGCACATTTCCCTCT-3' and 5'AAGGCACAAAACCTGCAGTAA- $3^{\prime}$. Equal amounts of cDNA template were used for each PCR analysis of Bim, $\alpha$-tubulin, Eefla, or glyceraldehyde-3phosphate dehydrogenase (GAPDH). Quantitative PCR was performed using a Cepheid (Sunnyvale, CA) SmartCycler following the manufacturer's specifications. GAPDH was used for normalization of human Bim transcripts and $\alpha$-tubulin or Eefla was used for rat Bim transcript normalization. cDNA was added to a $25 \mu \mathrm{l}$ volume reaction mix containing Ready-to-Go Beads (GE Healthcare, Piscataway, NJ) or OmniMix HS master mix (Cepheid) and SYBR Green I (Invitrogen) together with appropriate primers at $0.2 \mu \mathrm{M}$ each. Analyses of growth curves of real-time fluorescence and of melting curves were performed as described previously (Troy et al., 2000).

Staining of human $A D$ and control brain sections. Alzheimer's disease and control brain samples (supplemental Table 1, available at www. jneurosci.org as supplemental material) were obtained at autopsy by the New York Brain Bank at Columbia University (Dr. J.-P. Vonsattel, Director) as described in their website (http://nybb.hs.columbia.edu/ index.htm) (Vonsattel et al., 1995) under a protocol approved by the institutional review board. The criteria applied for assigning the diagnosis of Alzheimer's disease were that of "The National Institute on Aging, and Reagan Institute Working Group on Diagnostic Criteria for the Neuropathological Assessment of Alzheimer's Disease"; and that of CERAD (Consortium to Establish a Registry for Alzheimer's Disease). Two blocks were harvested fresh from one-half of each brain. The blocks were frozen in liquid nitrogen vapor at $-160^{\circ} \mathrm{C}$. One block included the rostral entorhinal area with gyrus ambient and amygdaloid nucleus. The other block included the cerebellar cortex and dentate nucleus. Contralateral mirror image blocks were fixed in $10 \%$ buffered formalin phosphate, and then paraffin embedded and processed for evaluation of the tissue using conventional neuropathology methods. A set of sections from each paraffin-embedded block was stained according the Bielschowsky protocol. In addition, sections were subjected to antibodies directed against $\beta$-amyloid, ubiquitinated proteins, $\alpha$-synuclein, and hyperphosphorylated tau (AT8). Frozen sections were prepared from the rostral entorhinal area with gyrus ambient and amygdaloid nucleus and cerebellum of $\mathrm{AD}$ (moderate to severe) and control patients (for information such as patient age, gender, postmortem interval, and neuropathological diagnosis, see supplemental Table 1, available at www.jneurosci.org as supplemental material). Sections of the rostral entorhinal area with gyrus ambient and amygdaloid nucleus included three clearly discernable lay- a)
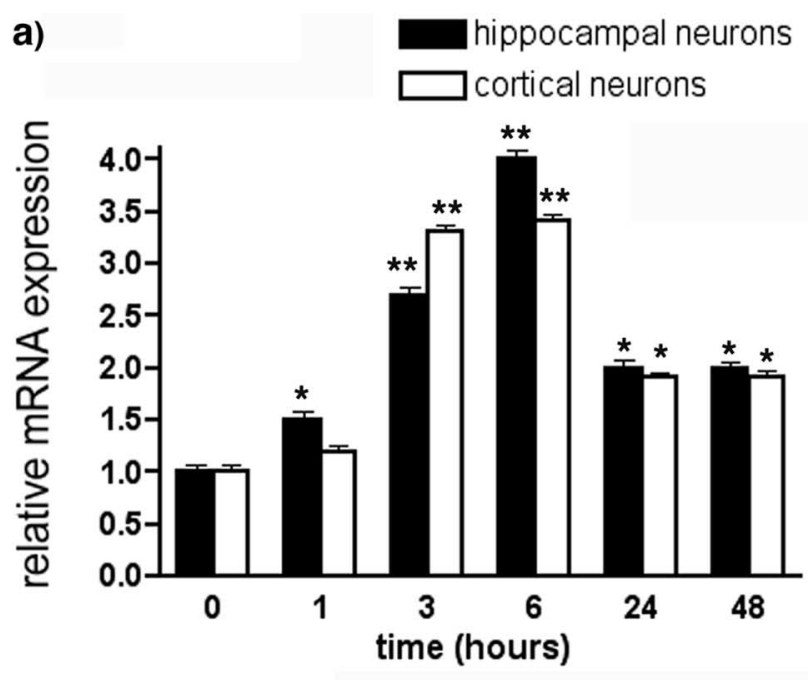

b) Hippocampal neurons

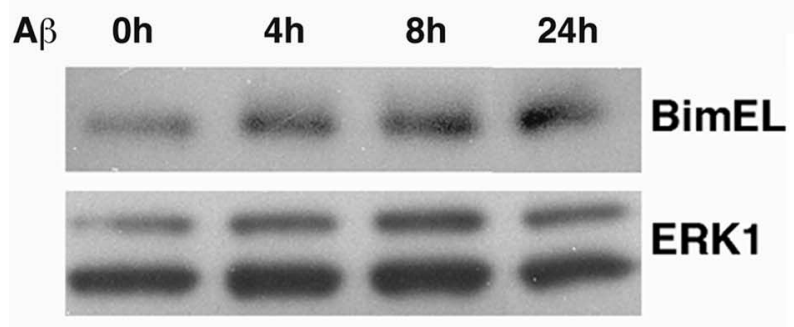

\section{c) Cortical neurons}

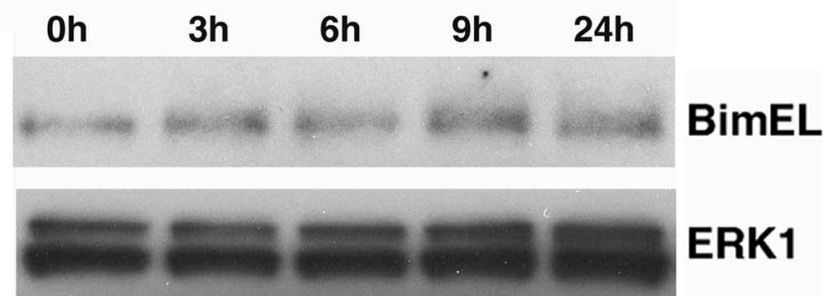

Figure 1. Bim is induced by $A \beta$ in cultured hippocampal and cortical neurons. $\boldsymbol{a}$, Bim mRNA levels are increased in response to $A \beta$. Hippocampal and cortical neurons were treated with 10 $\mu \mathrm{MA} \beta$ for the indicated times and total RNA was isolated, reverse transcribed, and amplified by PCR using Bim and $\alpha$-tubulin- or Eef1a-specific primers. Data represent means \pm SD of three experiments (hippocampal neurons) or two experiments (cortical neurons). The asterisks denote statistically significant differences from control $(0 \mathrm{~h}):{ }^{*} p<0.001 ;{ }^{* *} p<0.0001 . \boldsymbol{b}, \boldsymbol{c}, A \beta$ induces Bim protein levels. Hippocampal (b) and cortical (c) neurons were treated with $10 \mu \mathrm{m}$ $A \beta$ for the indicated times, and cell proteins were subjected to Western immunoblotting using enhanced chemiluminescence for the expression of Bim and ERK (loading control).

ers of the six present, and nearby amygdala. Staining of sections on the contralateral side for tau and by the Bielschowsky method confirmed the presence of Alzheimer changes including amyloid plaques and tangles. Tissue sections were $10 \mu \mathrm{m}$ thick and immunostained as described in Angelastro et al. (2003). Briefly, sections were blocked in 3\% nonimmune goat serum and $0.3 \%$ Triton X-100 for $1 \mathrm{~h}$. The sections were then incubated with rabbit anti-Bim (1:500; Calbiochem, La Jolla, CA) antiserum and mouse anti-NeuN (1:100; Chemicon) antibody or mouse anti-cdk4 (1:500; Cell Signaling) antibody or mouse phospho-Rb (1:500; Cell Signaling) antibody in blocking solution overnight at $4^{\circ} \mathrm{C}$, followed by secondary labeling with goat anti-rabbit (1:4000; Alexa Fluor 568; 


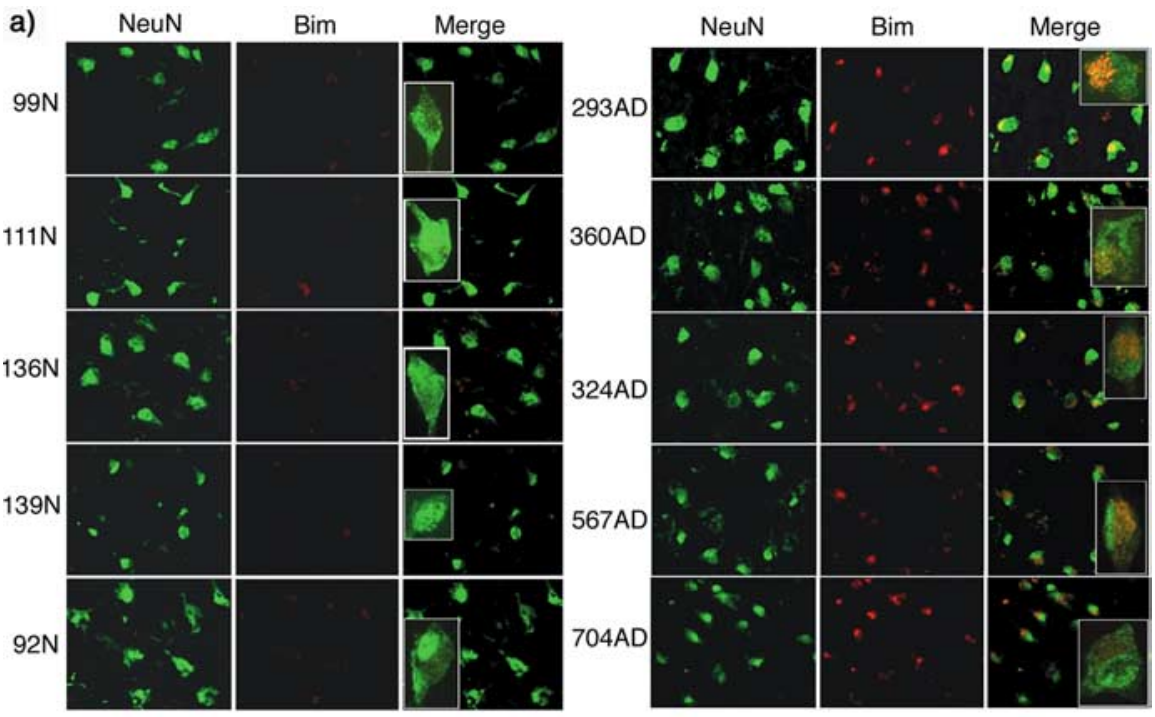

b)

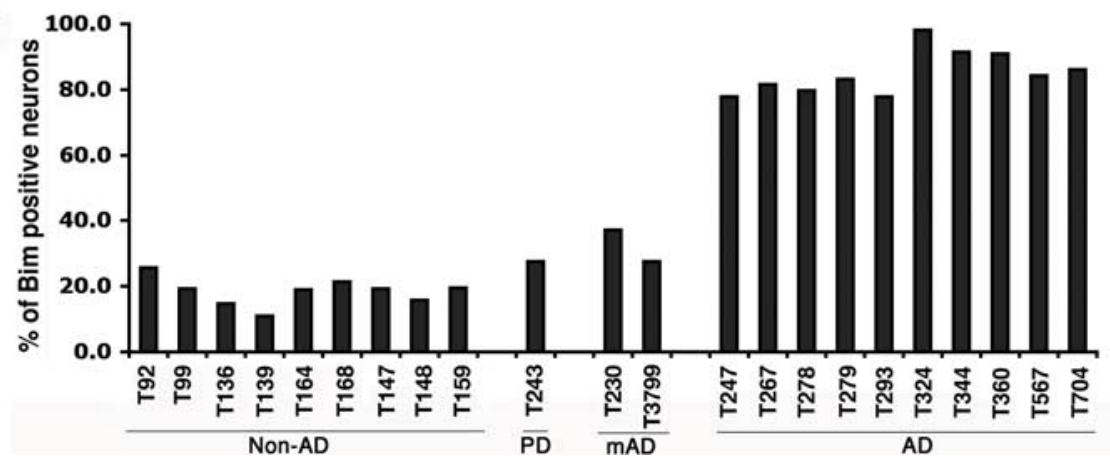

Figure 2. Bim immunostaining is elevated in entorhinal cortical neurons of AD brains. $\boldsymbol{a}$, Sections of entorhinal cortex of $10 \mathrm{AD}$, 9 non-AD controls, 1 PD, and 2 mild AD (mAD) brains were immunostained for Bim and NeuN. Representative images were taken for each case by using an inverted fluorescent microscope and camera set to the same exposure. The inset is a single neuron from the same section in each case but imaged by using a confocal microscope. Representative images are shown from five non- $A D$ control (N) and five AD brains. $\boldsymbol{b}$, NeuN-positive neurons with or without Bim staining were counted in layers 2 and 3 of the entorhinal cortex in brains from non-AD, mAD, PD, and AD patients. More than 100 cells were evaluated per case.

Invitrogen) and goat anti-mouse antibodies (1:4000; Alexa Fluor 488; Invitrogen) in blocking solution for $1 \mathrm{~h}$. Finally, slides were covered with glass coverslips using mounting solution. No staining was observed when primary antisera/antibodies were omitted. As another indication of the staining specificity of the anti-Bim antiserum, no staining of cultured cells was observed after transfection with Bim small hairpin RNA (shRNA).

Immunostaining of cultured neurons. Cortical neurons were transfected as indicated with appropriate constructs of shRNA in $500 \mu \mathrm{l}$ of serum free medium per well in 24-well dishes using LipofectAMINE 2000. Six hours later, medium with LipofectAMINE 2000 was replaced with fresh complete medium. Forty-eight hours later, cells were exposed to aggregated $10 \mu \mathrm{M} \mathrm{A} \beta_{1-42}$ for $6 \mathrm{~h}$ or $1 \mu \mathrm{M}$ oligomeric $\mathrm{A} \beta$ for $18 \mathrm{~h}$, and then immunostained as described in Angelastro et al. (2003). Briefly, neurons were fixed with $4 \%$ paraformaldehyde for $10 \mathrm{~min}$. After three washes in PBS, cells were blocked in 3\% nonimmune goat serum for $2 \mathrm{~h}$. The cultures were immunolabeled with rabbit anti-Bim (1:500; StressGen) antibody in $3 \%$ nonimmune goat serum overnight at $4^{\circ} \mathrm{C}$, followed by secondary labeling with goat anti-rabbit antibody (1:4000; Alexa Fluor 568; Invitrogen) for $1 \mathrm{~h}$.

Survival assays. Cortical neurons were cotransfected with either pSIREN-cdk4-shRNA, pSIREN-Luc-shRNA, pSIREN-Bim-shRNA, or a control pSIREN-ZsGreen (to see the transfected cells) and empty pU6 or pU6-B-myb-shRNA, and then $48 \mathrm{~h}$ later treated with aggregated $10 \mu \mathrm{M}$ $\mathrm{A} \beta_{1-42}$ or $1 \mu \mathrm{M}$ oligomeric $\mathrm{A} \beta$. The numbers of surviving transfected (green) cells per well were assessed by a blinded observer just before or after treatment and at 24 and $48 \mathrm{~h}$ after $\mathrm{A} \beta$ exposure as described previously (Liu and Greene, 2001). There was a 13-28\% death of cells attributable to transfection alone without any treatment, and data were normalized taking this into consideration. Data represent means \pm SEM of three experiments performed in triplicate.

Statistics. All experiments were performed at least in triplicate, and results are presented as means \pm SEM with an exception in Figure 1 in which the result is presented as mean \pm SD of two experiments. Student's $t$ test was used to evaluate the significance of differences between means and was performed as unpaired, twotailed sets of arrays and presented as $p$ values. In the case of multiple comparisons as in Figure 2 in which two $t$ tests were used, Bonferroni's adjustment was applied and a value of $p<0.025$ was considered to be a significant difference.

\section{Results}

$\boldsymbol{\beta}$-Amyloid upregulates Bim in cultured hippocampal and cortical neurons

Hippocampal and cortical neurons are severely affected in $\mathrm{AD}$ brains and both undergo death after exposure to aggregated or oligomeric $\mathrm{A} \beta$ protein in vitro (Pike et al., 1991; Estus et al., 1997; Troy et al., 2000; Barghorn et al., 2005). A time course revealed that Bim is upregulated by aggregated $\mathrm{A} \beta_{1-42}$ in both neuron types in culture. Bim transcript levels increased by threefold to fourfold within $6 \mathrm{~h}$ of exposure (Fig. 1a). Bim extra large (BimEL) protein expression was also elevated by 3-4 h and was maximally induced by $8-9$ $\mathrm{h}$ (Fig. 1b,c). Under the conditions of our experiment, neuron death first becomes apparent by $\sim 12-16$ h of $A \beta$ exposure and $\sim 50 \%$ of neurons die within $24 \mathrm{~h}$. Thus, maximal Bim induction by $\mathrm{A} \beta$ precedes overt signs of neuron death.

\section{Bim is elevated in entorhinal cortical neurons of AD brains}

We next determined whether Bim transcripts and protein are elevated in postmortem brains derived from $\mathrm{AD}$ patients. Immunohistochemical staining of $10 \mathrm{AD}$ and 9 control non-AD brains revealed that Bim levels were consistently elevated in the entorhinal cortex of $\mathrm{AD}$ brains where its localization appeared to be exclusively in neurons (identified by costaining with the neuronal marker NeuN) (Fig. 2a). The sections used in our study contained three clearly distinct cortical layers (of the six present in this area) of the rostral entorhinal area with gyrus ambient and amygdaloid nucleus. Examination of pathological changes in contralateral tissue revealed deposition of amyloid plaques and tangles in layers 2 and 3 as well as in nearby amygdala and it was in these areas that Bim-stained neurons were present. In contrast, layer 1 was relatively preserved with little presence of Alzheimer changes or Bim-positive cells (data not shown). Quantitation of Bim-positive neurons in layers 2 and 3 revealed that on average $85 \pm 2.2 \%(n=10)$ of NeuN-positive cells were Bim positive in AD brains, whereas only $18.4 \pm 1.5 \%(n=9)$ of neurons were Bim positive in the same areas of control non-AD brains (Fig. 2b). The difference between the means of the two populations was 
a) Cerebellum

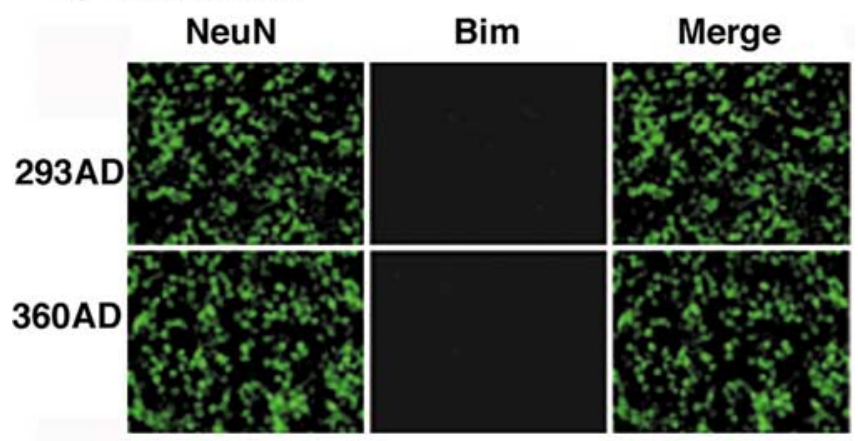

b)

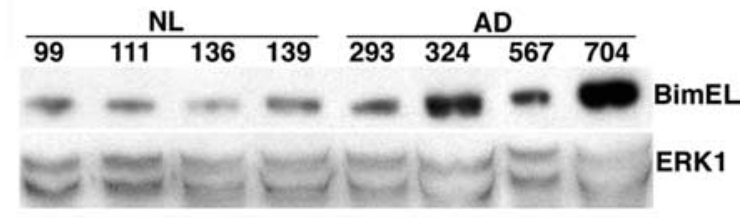

c)

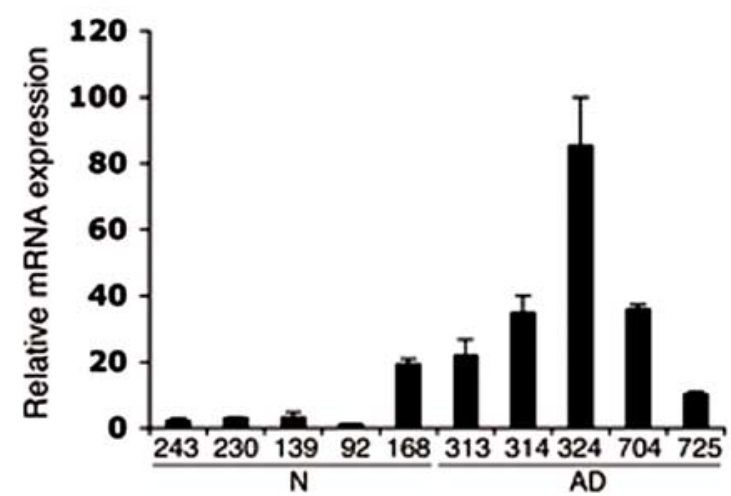

Figure 3. Bim expression is not elevated in cerebellum of AD brains, but Bim protein and transcripts are elevated in AD entorhinal cortex. $\boldsymbol{a}$, Bim is not elevated in cerebellar neurons of AD brains. Sections of cerebellum from two AD brains were immunostained for Bim and NeuN as in Figure 2. Representative images were taken using an inverted fluorescent microscope set to the same exposure as in Figure 2. $\boldsymbol{b}$, Bim protein levels are increased in entorhinal cortex of $A D$ brains. Portions of entorhinal cortex from $A D$ and control cases (NL) were dissolved in $2 \times$ gel loading buffer, and tissue proteins were subjected to Western immunoblotting as in Figure $1 c$. A fifth pair of samples (data not shown) also revealed elevation of Bim protein. c, Bar diagram showing the relative expression of Bim mRNA in samples prepared from entorhinal cortex of five $A D$ and five control cases (N). Data represent the means \pm range of two real-time RT-PCR analyses and are expressed relative to that of GAPDH in the same RNA pool.

highly significant ( $p<0.0001)$. Additionally, brains of two aged patients with mild $\mathrm{AD}$-like changes in morphology, but no known cognitive deficits (supplemental Table 1, available at www. jneurosci.org as supplemental material) and of one patient with moderate Parkinson's disease (PD) showed an average $30.7 \pm$ $3.8 \%$ Bim-positive neurons, which is significantly lower than in brains from $\mathrm{AD}$ patients $(p<0.0001)$. Even when detected in control non-AD and mild $\mathrm{AD}$ or $\mathrm{PD}$ brains, Bim staining was generally far less intense than in $\mathrm{AD}$ brains (Fig. 2a). We also examined cerebellar granule neurons a population apparently unaffected in AD. In this case, Bim was not elevated in either control or $\mathrm{AD}$ material (Fig. $3 a$ ). It has been reported that $\mathrm{A} \beta_{25-35}$ induces Bim and Bim-dependent death in cultured cerebral en-

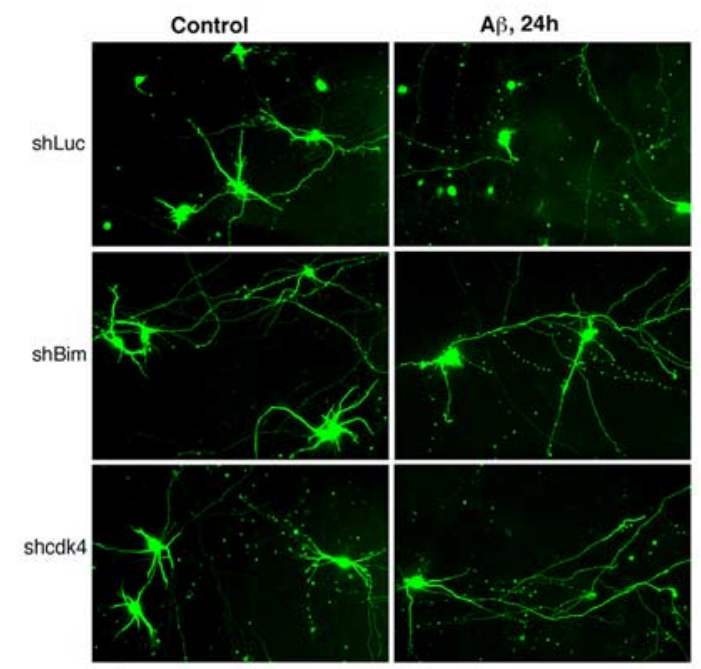

b)

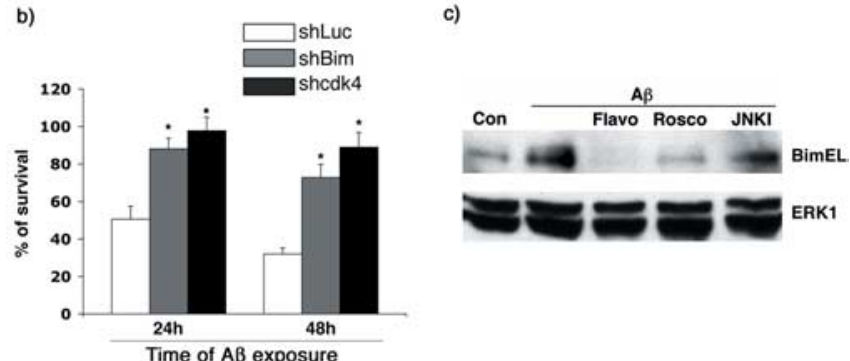

Figure 4. Bim and $c d k 4$ are required for neuron death evoked by $A \beta$. $\boldsymbol{a}$, Bim knock-down prevents neuronal degeneration and death after $A \beta$ treatment. Cortical neurons were transfected with pSIREN-Luc-shRNA-GFP (shLuc), pSIREN-Bim-shRNA-ZsGreen (shBim), or pSIRENcdk4-shRNA-ZsGreen (shcdk4), maintained for $48 \mathrm{~h}$, and then treated with $10 \mu \mathrm{m} \mathrm{A} \beta$ as indicated. Representative images of transfected neurons were taken in each case after $24 \mathrm{~h}$ of treatment. $\boldsymbol{b}$, Bim shRNA and cdk4 shRNA provide protection against death evoked by A $\beta$. Cortical neurons were transfected with pSIREN-Luc-shRNA-GFP (shLuc), pSIREN-Bim-shRNAZsGreen (shBim), or pSIREN-cdk4-shRNA-ZsGreen (shcdk4), maintained for $48 \mathrm{~h}$, and then treated with $10 \mu \mathrm{m} \mathrm{A} \beta$ as indicated. Numbers of surviving transfected (green) cells were counted just before treatment and after 24 and $48 \mathrm{~h}$ with or without treatment. Data represent means \pm SEM of three experiments performed in triplicate. The asterisks denote statistically significant differences from control (shLuc): ${ }^{*} p<0.001$. c, The induction of the Bim protein by $A \beta$ is completely blocked by cdk inhibitors and incompletely blocked by a JNK inhibitor. Cortical neurons were treated with $A \beta$ for $24 \mathrm{~h}$ in presence or absence of $1 \mu \mathrm{m}$ flavopiridol (Flavo), 20 $\mu \mathrm{m}$ roscovitine (Rosco), or $10 \mu \mathrm{m}$ JNK inhibitor (JNKI) (SP600125), and cell proteins were subjected to Western immunoblotting as in Figure $1 c$.

dothelial cells (Yin et al., 2002). However, we did not detect specific staining of cell types other than neurons in our sections.

Western immunoblots performed on isolated entorhinal cortex from a portion of the same brains confirmed BimEL protein expression and indicated (relative to ERK protein) increased BimEL levels in four of the five AD samples (exception, brain AD293) compared with controls (Fig. 3b) (data not shown). Quantification revealed that there was a significant difference in relative levels of Bim in entorhinal cortex derived from non-AD control and $\mathrm{AD}$ patients $(1.0 \pm 0.02$ vs $1.5 \pm 0.06$, relative to ERK1; mean \pm SEM; $p<0.05)$. This is consistent with a previous report in which Western immunoblotting indicated an increase of Bim protein in extracts of AD cerebral cortex, but not of cerebellum (Engidawork et al., 2001). Finally, as determined by quantitative real-time PCR, there was a significant difference in relative levels of Bim transcripts in entorhinal cortex isolated from $\mathrm{AD}$ and non-AD controls ( $38 \pm 14$ vs $6 \pm 4$, relative to GAPDH transcripts; mean \pm SEM; $p<0.05$ ) (Fig. $3 c$ ). The degree of 
variability in protein and mRNA levels in the AD material could reflect in part differences in the numbers of surviving neurons (and the consequent ratios of neuronal to non-neuronal tissue and of affected to nonaffected neurons) as well as the relative stabilities of these molecules in postmortem tissues. The loss of neurons in $\mathrm{AD}$ would tend to decrease the apparent changes of Bim expression detected in bulk tissue. Together, these findings indicate that BimEL protein levels are elevated in both a cellular model of $\mathrm{AD}$ and in relevant neurons of $\mathrm{AD}$ patients and that these changes reflect increases in Bim mRNA.

\section{Bim plays a required role in neuron death evoked by $A \beta$ in a cellular model of AD}

Because Bim has been shown to have proapoptotic activity and plays a role in neuron death evoked by apoptotic signals such as NGF deprivation and seizure, we next assessed whether Bim induction is required for neuron death evoked by $\mathrm{A} \beta$. To achieve this, we used a shRNA construct specifically targeted to Bim, based on a previously described similar human target sequence (Reginato et al., 2003) and the efficacy of which has been described previously in our system (Biswas et al., 2005) (see also Fig. 5 ). As shown in Figure 4, $a$ and $b$, compared with an irrelevant shRNA (shLuc), the Bim shRNA significantly protected cultured cortical neurons from aggregated $A \beta_{1-42}$. There was more than a twofold increase in surviving neurons after 24 and $48 \mathrm{~h}$ of $\mathrm{A} \beta$ exposure (Fig. $4 b$ ) with good preservation of overall neuron morphology (Fig. 4a). The specificity of Bim shRNA silencing was confirmed by overexpressing a silencing-resistant Bim (short isoform of Bim) that restored $\mathrm{A} \beta$-induced death of cultured cortical neurons (supplemental Fig. 1, available at www.jneurosci.org as supplemental material). No protection was additionally seen with an empty U6 vector (see Fig. 6) or with a shRNA targeting no known sequence (supplemental Fig. 1, available at www.jneurosci. org as supplemental material). Thus, in a cellular model of AD, Bim plays an essential role in neuron death.

\section{Cell cycle-related proteins are required for Bim induction by $\mathrm{A} \boldsymbol{\beta}$}

It has been observed that cell cycle-related proteins are elevated in susceptible neurons of $\mathrm{AD}$ patients and that such molecules play essential roles in neuron death associated with a variety of paradigms of neuron death (Greene et al., 2004; Herrup et al., 2004). Of particular relevance, there is pharmacological and molecular evidence that $\mathrm{cdk} 4$ is required for death of cultured cortical neurons evoked by $\mathrm{A} \beta$ (Giovanni et al., 1999), and it is reported that cdk4 levels are elevated in AD neurons (Busser et al., 1998). In addition, we recently found that, in NGF-deprived cells, Bim is a target of a neuronal apoptotic pathway dependent on elevated cdk4 activity and consequent de-repression of E2F-regulated $M y b$ genes (Biswas et al., 2005). We therefore assessed the possibility that Bim induction in a cellular model of $\mathrm{AD}$ requires $\mathrm{cdk} 4$ and Myb. As an initial test, we applied $A \beta$ to cultured cortical neurons in presence of the cdk inhibitors flavopiridol and roscovitine and measured Bim expression by Western immunoblotting. Past work has shown that these inhibitors protect neurons from apoptotic death evoked by A $\beta$ (Giovanni et al., 1999), and we also confirmed these results in our paradigm (supplemental Fig. 2, available at www.jneurosci.org as supplemental material). As shown in Figure $4 c$, these fully blocked $\mathrm{A} \beta$-evoked Bim induction. In contrast, anthra[1,9-cd]pyrazol-6(2H)-one (SP600125), an inhibitor of c-Jun N-terminal protein kinase activity (Bennett et al., 2001), only partially inhibited induction of Bim. These findings are similar to those we have previously reported for Bim
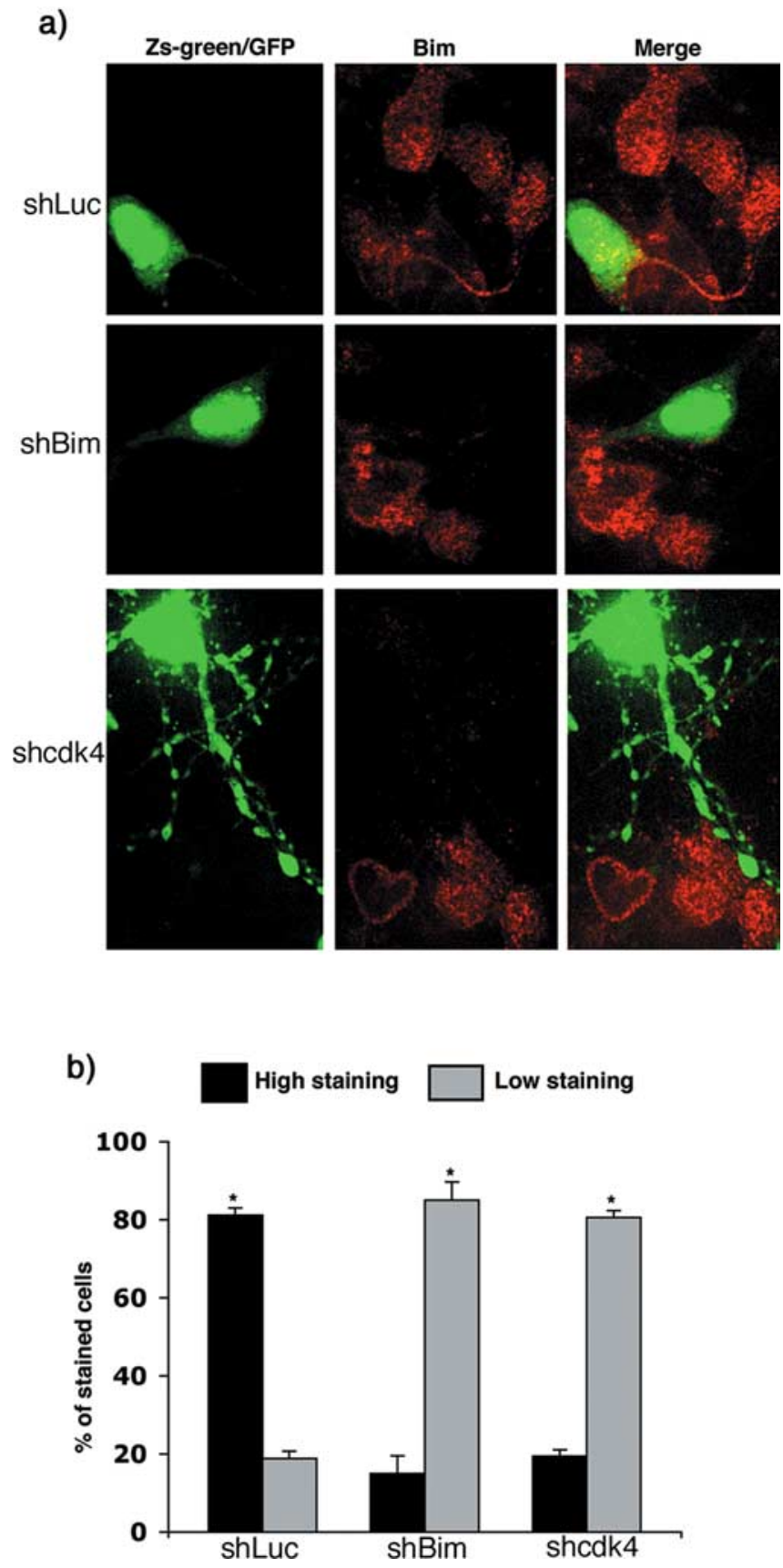

Figure 5. shRNAs targeted to Bim and cdk4 repress upregulation of endogenous Bim in cortical neurons subjected to $A \beta$ treatment. $\boldsymbol{a}, \boldsymbol{b}$, Cortical neurons were transfected with pSIREN-Luc-shRNA-GFP (shLuc), pSIREN-Bim-shRNA-ZsGreen (shBim), or pSIREN-cdk4-shRNAZsGreen (shcdk4), maintained for $48 \mathrm{~h}$, and then treated with $A \beta$ for $6 \mathrm{~h}$, after which they were immunostained with antibodies against Bim (red). Percentage of stained cells pertains to the proportions of transfected cells (green) that show Bim staining either greater than that in nontreated control neurons (high) or equal to or less than that of control, nontreated neurons (low). Data represent means \pm SEM of three experiments. Approximately 50 cells were evaluated per culture. The asterisks denote statistically significant differences between low staining cells and high staining cells: ${ }^{*} p<0.0001$.

induction evoked by NGF deprivation (Biswas et al., 2005). Because enzymatic inhibitors may lack specificity, we additionally used a previously characterized shRNA that targets cdk4 (Biswas et al., 2005). As shown in Figure 4, $a$ and $b$, the cdk4 shRNA effectively protects cultured cortical neurons from death evoked by $\mathrm{A} \beta$. Moreover, the shRNA substantially blocked the induction of endogenous Bim in cortical neurons after $A \beta$ exposure (Fig. 5). 
To test the potential role of Myb proteins in Bim induction and death promoted by $\mathrm{A} \beta$, we made use of a previously characterized B-myb shRNA (Liu et al., 2004; Biswas et al., 2005). In our past work, we found that $\mathrm{B}$ - and $\mathrm{C}-\mathrm{myb}$ regulated each another so that interfering with synthesis of either one was sufficient to protect from NGF deprivation (Liu et al., 2004). Here, we observed that B-myb shRNA provided significant protection of cultured cortical neurons from death evoked by $\mathrm{A} \beta$ and blocked the induction of endogenous Bim in cortical neurons after $\mathrm{A} \beta$ exposure (Fig. 6). Together, these findings support the conclusion that cell cycle-related proteins are required for Bim induction and neuron death in response to $A \beta$.

Bim is coexpressed with cell cyclerelated proteins in $\mathrm{AD}$ brains

As noted above, dysregulated levels of cell cycle-related proteins have been reported in vulnerable neuronal populations of $\mathrm{AD}$ brains. If, as found in our cell culture studies, Bim is a target of such molecules, then it should be present in neurons that express such proteins. To test this, we costained $\mathrm{AD}$ and control non-AD entorhinal cortex for expression of Bim and either cdk4 or phospho-Rb. Rb is a target of cdk4 that undergoes enhanced phosphorylation in AD neurons (Busser et al., 1998) and that, along with other members of the $\mathrm{Rb}$ family, regulates expression of Mybs in neurons (Liu et al., 2004). As shown in Figure 7, high levels of Bim immunoreactivity appeared to be present exclusively in $\mathrm{AD}$ neurons that were also highly positive for $\mathrm{cdk} 4$ and phospho-Rb (and vice versa). Moreover, like Bim, cdk4 and phospho-Rb expression within the same sets of brains (control and AD) was not elevated in cerebellar granule neurons (data not shown). These findings thus indicate that elevated Bim is coexpressed in vulnerable $\mathrm{AD}$ neurons that show activation of cell cycle-related proteins.

\section{Discussion}

The molecular chain of events that lead to death of neurons in AD is incompletely understood and any progress in this regard has the possibility to identify potential targets for therapeutic intervention. Our findings now implicate the proapoptotic Bcl-2 family member Bim in neuron death associated with $\mathrm{AD}$. We show that Bim transcripts and protein are elevated in the entorhinal cortex of postmortem AD brains and that the elevation of Bim expression is limited to vulnerable populations within layers of this structure that possess plaques and tangles. In contrast, neurons in layer 1 of the entorhinal cortex and in the cerebellum that are spared in $\mathrm{AD}$, did not exhibit elevated Bim protein. Additional complementary studies using cultures of cortical and hippocampal neurons (which are neuron types that are vulnerable in $\mathrm{AD})$ further support a role for Bim in $\mathrm{AD}$ and link induction of this molecule to $A \beta$ and to $A \beta$-dependent neuron death. That is, exposure of such cultures to $A \beta$ induced Bim mRNA and protein, whereas downregulation of Bim using shRNA protected the neurons from $\mathrm{A} \beta$-dependent toxicity.

Our immunostaining results indicate that a large proportion of vulnerable neurons in the entorhinal cortex of AD brains have elevated expression of Bim. Given that overexpression of Bim in cultured neurons induces a rapid apoptotic death (Whitfield et al., 2001), this raises the potential question as to why neuron death in $\mathrm{AD}$ is progressive and relatively prolonged despite apparent widespread Bim induction. One potential explanation is that, in addition to being induced, Bim must be appropriately modified to promote neuron death. There is evidence that Bim must be activated by c-Jun N-terminal kinase (JNK)-dependent phosphorylation to induce death of neurons (Putcha et al., 2003; Becker et al., 2004). Moreover, the proapoptotic activity of Bim appears to be suppressed by growth factor-stimulated phosphorylation via the ERK pathway (Biswas and Greene, 2002). An additional possibility is that a second event must occur to permit Bim-evoked neuron death. For example, it was recently reported that $\mathrm{A} \beta_{25-35}$ downregulates the antiapoptotic molecule bcl-w in cultured cortical neurons and that this effect plays a role in death evoked by the peptide (Yao et al., 2005). Thus, Bim induction may play a necessary, but not sufficient role in neuron death associated with $\mathrm{AD}$. Suitable genetic animal models of $\mathrm{AD}$ that include neuron death will be helpful to further evaluate the in vivo role of Bim in this disorder. 


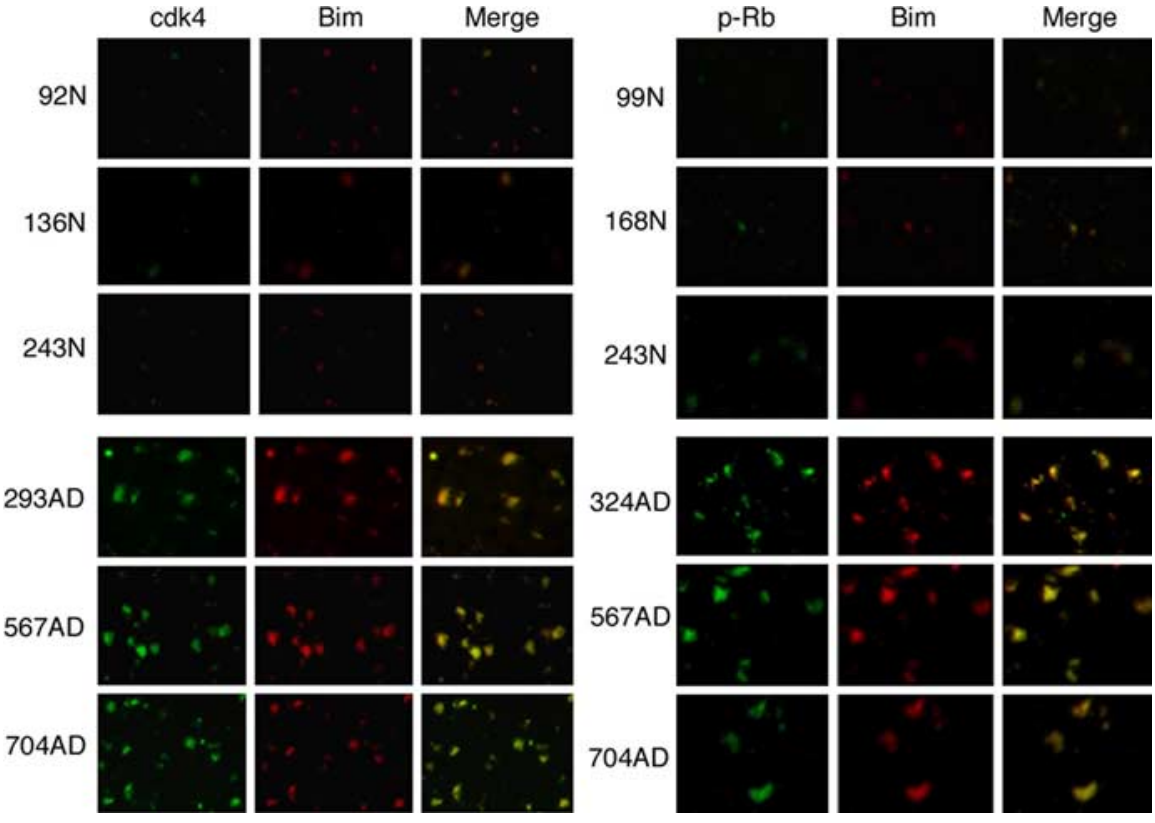

Figure 7. Entorhinal cortical neurons of $A D$ brains that show elevated cdk4 and phospho- $\mathrm{Rb}(\mathrm{p}-\mathrm{Rb})$ immunostaining also show elevated immunostaining of Bim. Sections of entorhinal cortex of three AD and three controls (N) were coimmunostained for Bim and cdk4 or $\mathrm{p}-\mathrm{Rb}$. Representative images were taken for each case by using an inverted fluorescent microscope and camera set to the same exposure.

The elevated expression of cell cycle-related proteins including cdk4 in AD neurons has been widely recognized (cf. Busser et al., 1998; Greene et al., 2004; Herrup et al., 2004; Webber et al., 2005). However, despite much speculation, the potential role of such molecules in the pathophysiology of $\mathrm{AD}$ has been less clear as have been the mechanisms by which they might trigger neuron death. In vitro experiments using pharmacologic cdk inhibitors and dominant-negative constructs have previously implicated cdk4 in neuron death evoked by A $\beta$ (Giovanni et al., 1999, 2000). However, such reagents can possess nonspecific activities and it is significant that our use of shRNA directed to $\mathrm{cdk} 4$ corroborates this molecule as a required mediator of $A \beta$-dependent neuron toxicity.

Our cell culture findings along with observations in $\mathrm{AD}$ brains begin to outline a sequential molecular pathway of events by which cell cycle-related molecules link $\mathrm{A} \beta$ exposure with neuron death. cdk4 is elevated in AD neurons and past and present culture studies show that this molecule and its activity are essential for $\mathrm{A} \beta$-induced neuron death. Among the major targets for activated $c d k 4$ are members of the Rb family and these are hyperphosphorylated both in AD neurons (Ranganathan et al., 2001) and in A $\beta$-treated cultured neurons (Giovanni et al., 1999). Although the mechanism by which Rb family hyperphosphorylation might promote neuron death in response to $\mathrm{A} \beta$ has not been studied in detail, our recent findings on the role of cell cycle molecules in neuron death evoked by loss of trophic support (Liu and Greene, 2001; Liu et al., 2004, 2005; Biswas et al., 2005) may provide significant insight in this regard. NGF deprivation leads to activation of cdk4 and hyperphosphorylation of $\mathrm{Rb}$ family proteins. Once hyperphosphorylated in response to NGF deprivation, $\mathrm{Rb}$ proteins dissociate from DNA-bound transcriptionsilencing complexes comprising the transcription factor E2F and the chromatin modifiers Suv39H1 and histone deacetylase. This dissociation results in gene derepression. Among the genes that are de-repressed under such circumstances are the transcription factors B- and C-myb. The promoter for Bim contains a myb binding site and, as a consequence of the chain of events triggered by trophic factor deprivation, this becomes occupied by mybs and results in Bim induction and neuron death. Our present study now reveals that B-myb is also a required mediator of Bim induction as well as of neuron toxicity after $\mathrm{A} \beta$ exposure. Thus, it appears that a similar cdk4-dependent apoptotic pathway plays an essential role in Bim induction after $A \beta$ exposure as in neurotrophic deprivation of neurons. Thus, we propose that $A \beta$ sequentially leads to cdk4 activation, hyperphosphorylation of $\mathrm{Rb}$ family members, de-repression of $\mathrm{B}$ - and $\mathrm{C}-\mathrm{myb}$, and induction of the deathpromoting molecule Bim.

In the present study, we found that essentially all AD neurons that we examined with elevated cdk4 or phospho-Rb also exhibit elevated Bim expression. This is consistent with and supports the possibility that the cell cycle molecule pathway outlined above also occurs in AD neurons and culminates in induction of proapoptotic Bim.

Although we have used acute $\mathrm{A} \beta$ exposure to link cdk4, Bim induction, and neuron death, there are other potential means by which Bim may be elevated in AD. For example, loss of synaptic connections and axonal degeneration seen in this disorder (Spires and Hyman, 2004) (whether triggered by $A \beta$ or other causes) could result in failure of transsynaptic supply and/or retrograde transport of trophic molecules such as NGF. Such loss of trophic support would also lead to cdk4-dependent Bim elevation and consequent neuron death by the mechanisms discussed above.

In summary, our findings show that expression of the proapoptotic protein Bim is significantly elevated in a vulnerable population of neurons in $\mathrm{AD}$ brains. Additionally, we find that $\mathrm{Bim}$ is induced by the $\mathrm{AD}$-associated $\mathrm{A} \beta$ peptide in cultured neurons and plays an essential role in $\mathrm{A} \beta$-dependent neuron death. Finally, induction of Bim and of neuron death by A $\beta$ appear to be mediated by pathway that includes the cell cycle molecule cdk4 and myb. These observations thus suggest that both the product of this pathway (Bim) and the cell cycle-related proteins involved in its induction appear to be potential targets for therapeutic intervention in $\mathrm{AD}$.

\section{References}

Angelastro JM, Ignatova TN, Kukekov VG, Steindler DA, Stengren GB, Mendelsohn C, Greene LA (2003) Regulated expression of ATF5 is required for the progression of neural progenitor cells to neurons. J Neurosci 23:4590-4600.

Barghorn S, Nimmrich V, Striebinger A, Krantz C, Keller P, Janson B, Bahr M, Schmidt M, Bitner RS, Harlan J, Barlow E, Ebert U, Hillen H (2005) Globular amyloid b-peptide 1-42 oligomer-a homogenous and stable neuropathological protein in Alzheimer's disease. J Neurochem 95:834-847.

Becker EB, Howell J, Kodama Y, Barker PA, Bonni A (2004) Characterization of the c-Jun N-terminal kinase-BimEL signaling pathway in neuronal apoptosis. J Neurosci 24:8762-8770.

Bennett BL, Sasaki DT, Murray BW, O’Leary EC, Sakata ST, Xu W, Leisten JC, Motiwala A, Pierce S, Satoh Y, Bhagwat SS, Manning AM, Anderson DW (2001) SP600125, an anthrapyrazolone inhibitor of Jun N-terminal kinase. Proc Natl Acad Sci USA 98:13681-13686. 
Biswas SC, Greene LA (2002) Nerve growth factor (NGF) down-regulates the Bcl-2 homology 3 (BH3) domain-only protein Bim and suppresses its proapoptotic activity by phosphorylation. J Biol Chem 277:49511-49516.

Biswas SC, Liu DX, Greene LA (2005) Bim is a direct target of a neuronal E2F-dependent apoptotic pathway. J Neurosci 25:8349-8358.

Busser J, Geldmacher DS, Herrup K (1998) Ectopic cell cycle proteins predict the sites of neuronal cell death in Alzheimer's disease brain. J Neurosci 18:2801-2807.

Cotman CW, Su JH (1996) Mechanisms of neuronal death in Alzheimer's disease. Brain Pathol 6:493-506.

Cotman CW, Whittemore ER, Watt JA, Anderson AJ, Loo DT (1994) Possible role of apoptosis in Alzheimer's disease. Ann NY Acad Sci 747:36-49.

Engidawork E, Gulesserian T, Seidl R, Cairns N, Lubec G (2001) Expression of apoptosis related proteins in brains of patients with Alzheimer's disease. Neurosci Lett 303:79-82.

Estus S, Tucker HM, van Rooyen C, Wright S, Brigham EF, Wogulis M, Rydel RE (1997) Aggregated amyloid- $\beta$ protein induces cortical neuronal apoptosis and concomitant "apoptotic" pattern of gene induction. J Neurosci 17:7736-7745

Giovanni A, Wirtz-Brugger F, Keramaris E, Slack R, Park DS (1999) Involvement of cell cycle elements, cyclin-dependent kinases, $p R b$, and E2F $\times$ DP, in B-amyloid-induced neuronal death. J Biol Chem 274:19011-19016.

Giovanni A, Keramaris E, Morris EJ, Hou ST, O’Hare M, Dyson N, Robertson GS, Slack RS, Park DS (2000) E2F1 mediates death of B-amyloid-treated cortical neurons in a manner independent of p53 and dependent on Bax and caspase 3. J Biol Chem 275:11553-11560.

Greene LA, Biswas SC, Liu DX (2004) Cell cycle molecules and vertebrate neuron death: E2F at the hub. Cell Death Differ 11:49-60.

Ham J, Towers E, Gilley J, Terzano S, Randall R (2005) BH3-only proteins: key regulators of neuronal apoptosis. Cell Death Differ 12:1015-1020.

Hardy J (1997) Amyloid, the presenilins and Alzheimer's disease. Trends Neurosci 20:154-159.

Hartman RE, Izumi Y, Bales KR, Paul SM, Wozniak DF, Holtzman DM (2005) Treatment with an amyloid- $\beta$ antibody ameliorates plaque load, learning deficits, and hippocampal long-term potentiation in a mouse model of Alzheimer's disease. J Neurosci 25:6213-6220.

Herrup K, Neve R, Ackerman SL, Copani A (2004) Divide and die: cell cycle events as triggers of nerve cell death. J Neurosci 24:9232-9239.

Li YP, Bushnell AF, Lee CM, Perlmutter LS, Wong SK (1996) Beta-amyloid induces apoptosis in human-derived neurotypic SH-SY5Y cells. Brain Res 738:196-204

Linseman DA, Phelps RA, Bouchard RJ, Le SS, Laessig TA, McClure ML, Heidenreich KA (2002) Insulin-like growth factor-I blocks Bcl-2 interacting mediator of cell death (Bim) induction and intrinsic death signaling in cerebellar granule neurons. J Neurosci 22:9287-9297.

Liu DX, Greene LA (2001) Regulation of neuronal survival and death by E2F-dependent gene repression and derepression. Neuron 32:425-438.

Liu DX, Biswas SC, Greene LA (2004) B-myb and C-myb play required roles in neuronal apoptosis evoked by nerve growth factor deprivation and DNA damage. J Neurosci 24:8720-8725.

Liu DX, Nath N, Chellappan SP, Greene LA (2005) Regulation of neuron survival and death by p130 and associated chromatin modifiers. Genes Dev 19:719-732.

Masters CL, Multhaup G, Simms G, Pottgiesser J, Martins RN, Beyreuther K (1985) Neuronal origin of a cerebral amyloid: neurofibrillary tangles of Alzheimer's disease contain the same protein as the amyloid of plaque cores and blood vessels. EMBO J 4:2757-2763.

Park DS, Morris EJ, Padmanabhan J, Shelanski ML, Geller HM, Greene LA
(1998) Cyclin-dependent kinases participate in death of neurons evoked by DNA-damaging agents. J Cell Biol 143:457-467.

Pike CJ, Walencewicz AJ, Glabe CG, Cotman CW (1991) Aggregationrelated toxicity of synthetic beta-amyloid protein in hippocampal cultures. Eur J Pharmacol 207:367-368.

Putcha GV, Moulder KL, Golden JP, Bouillet P, Adams JA, Strasser A, Johnson EM (2001) Induction of BIM, a proapoptotic BH3-only BCL-2 family member, is critical for neuronal apoptosis. Neuron 29:615-628.

Putcha GV, Le S, Frank S, Besirli CG, Clark K, Chu B, Alix S, Youle RJ, LaMarche A, Maroney AC, Johnson Jr EM (2003) JNK-mediated BIM phosphorylation potentiates BAX-dependent apoptosis. Neuron 38:899-914.

Puthalakath H, Strasser A (2002) Keeping killers on a tight leash: transcriptional and post-translational control of the pro-apoptotic activity of $\mathrm{BH} 3$ only proteins. Cell Death Differ 9:505-512.

Ranganathan S, Scudiere S, Bowser R (2001) Hyperphosphorylation of the retinoblastoma gene product and altered subcellular distribution of E2F-1 during Alzheimer's disease and amyotrophic lateral sclerosis. J Alzheimers Dis 3:377-385.

Reginato MJ, Mills KR, Paulus JK, Lynch DK, Sgroi DC, Debnath J, Muthuswamy SK, Brugge JS (2003) Integrins and EGFR coordinately regulate the pro-apoptotic protein Bim to prevent anoikis. Nat Cell Biol 5:733-740.

Selkoe DJ (1999) Translating cell biology into therapeutic advances in Alzheimer's disease. Nature 399:A23-A31.

Selkoe DJ (2001) Alzheimer's disease results from the cerebral accumulation and cytotoxicity of amyloid beta-protein. J Alzheimers Dis 3:75-80.

Spires TL, Hyman BT (2004) Neuronal structure is altered by amyloid plaques. Rev Neurosci 15:267-278.

Stadelmann C, Deckwerth TL, Srinivasan A, Bancher C, Bruck W, Jellinger K, Lassmann H (1999) Activation of caspase-3 in single neurons and autophagic granules of granulovacuolar degeneration in Alzheimer's disease. Evidence for apoptotic cell death. Am J Pathol 155:1459-1466.

Troy CM, Rabacchi SA, Friedman WJ, Frappier TF, Brown K, Shelanski ML (2000) Caspase- 2 mediates neuronal cell death induced by $\beta$-amyloid. J Neurosci 20:1386-1392.

Troy CM, Rabacchi SA, Xu Z, Maroney AC, Connors TJ, Shelanski ML, Greene LA (2001) $\beta$-Amyloid-induced neuronal apoptosis requires c-Jun N-terminal kinase activation. J Neurochem 77:157-164.

Vonsattel JP, Aizawa H, Ge P, DiFiglia M, McKee AC, MacDonald M, Gusella JF, Landwehrmeyer GB, Bird ED, Richardson Jr EP, Hedley-Whyte ET (1995) An improved approach to prepare human brains for research J Neuropathol Exp Neurol 54:42-56.

Webber KM, Raina AK, Marlatt MW, Zhu X, Prat MI, Morelli L, Casadesus G, Perry G, Smith MA (2005) The cell cycle in Alzheimer disease: a unique target for neuropharmacology. Mech Ageing Dev 126:1019-1025.

Whitfield J, Neame SJ, Paquet L, Bernard O, Ham J (2001) Dominantnegative c-Jun promotes neuronal survival by reducing BIM expression and inhibiting mitochondrial cytochrome c release. Neuron 29:629-643.

Wisniewski HM, Wegiel J (1995) The neuropathology of Alzheimer's disease. Neuroimaging Clin N Am 5:45-57.

Yankner BA (1996) Mechanisms of neuronal degeneration in Alzheimer's disease. Neuron 16:921-932.

Yao M, Nguyen TV, Pike CJ (2005) $\beta$-Amyloid-induced neuronal apoptosis involves c-Jun N-terminal kinase-dependent downregulation of Bcl-w. J Neurosci 25:1149-1158.

Yin KJ, Lee JM, Chen SD, Xu J, Hsu CY (2002) Amyloid- $\beta$ induces Smac release via AP-1/Bim activation in cerebral endothelial cells. J Neurosci 22:9764-9770. 